\title{
Manajemen Madrasah dalam Perspektif Sejarah
}

\author{
Rini Setyaningsih \\ rinisetyaningsih@gmail.com \\ UIN Sultan Syarif Kasim Riau
}

\begin{abstract}
The Developing of madrassa from classical times to the present can not be treated partially or half-and-half, but requires thinking the development of a complete and comprehensive measures and efforts are visible, flexible and credible, especially when faced with the national development policy in education who have the vision of the educational system as a social institution that is strong and authoritative to empower all citizens of Indonesia develop into quality human, so capable and proactive answer the challenges of changing times (see explanation of Law No. 20/2003 on the National Education System). Plus era of globalization has given a wide impact in many aspects of life, including quality demands in the organization of education. In this era every field requires the Human Resources (HR) qualified high caliber and reliable, so competition especially concerning human resources are very tight. to meet this demand, the improvement and development of education provision in each madrasah system continuously needs to be done in line with the dynamic development of science as well as the dynamics of change in society itself that is the development of character concerning the aspects of soft skills (spirituality) and hard skills (intellect). Strengthening way blend of character development in the stretcher build madrassas ideals and a strong academic culture that lead to superior output and good as expected madrasah in this age of globalization. Surely madrasas must have good managerial system in realizing the goal of madrasa education in it self.
\end{abstract}

Keywords: development of madrasah management 


\section{A. PENDAHULUAN}

Perspektif sejarah Pendidikan Islam terutama madrasah pada umumnya lahir dan berkembang secara alamiyah dengan biaya seadanya. Keterlibatan masyarakat secara totalitas memang memiiki keinginan kuat dalam penyelengaraan pendidikan,mulai dari tinggkat dasar (Ibtidaiyah) sampai tingkat atas ('Aliyah).

Madrasah pernah membawa peradaban Islam kepuncak kejayaannya yang mempunyai peran aktif dalam pengembangan ilmu pengetahuan. AlNizamiyah, salah satu saksi bisu di Baghdad dalam pergulatan pengkajjian khazanah ke-intelektualan. Namun sangat disayangkan identitas madrasahyang dulu tidak tercermin lagi sekarang khususnya di negara Indonesia. Masyarakat sepertinya tidak bersahabat dengan madrasah dengan berbagai penilaian dan tolak ukur baik secara moral maupun moril sesuai dengan tuntutan masyarakat.

Sistem Pendidikan Nasional (SISDIKNAS) selama beberapa dekade terakhir pada dasarnya diatur oleh UU. No. 12 tahun 1945. Undang-undang ini berisi tentang dasar-dasar pendidikan dan pengajaran sekolah. Didalamnya ditegaskan bahwa tanggung jawab pemerintah hanya terbatas pada pada pengelolaan sekolah umum, tidak pada lembaga pendidikan lainya.

\section{B. PEMBAHASAN}

\section{Pengertian Madrasah.}

Perkataan madrasah berasal dari bahasa Arab yang artinya adalah tempat belajar. Madrasah dalam bahasa Indonesia sekolah yang lebih dikhususkan lagi sekolah-sekolah agama Islam. Dalam shoter encyclopedia of Islam, diartikan: “ Name of an institution where the
Islamic science are studied". Artinya; Nama dari suatu lembaga dimana ilmu keislaman diajarkan. ${ }^{1}$

Dengan keterangan tersebut dapat dipahami bahwa madrasah tersebut adalah penekananya adalah sebagai suatu lembaga yang mengajarkan ilmu-ilmu keislaman. Perkataan madrasaah ditanah Arab ditujukan untuk sekolah secara umum. Akan tetapi di Indonesia ditujukan buat sekolah-sekolah yang mempelajari ajaran-ajaran Islam. Madrasah pada prinsipnya adalah kelanjutan dari sistem pesantren.

Didunia pesantren terkenal dengan elemen-elemen pokok dari suatu pesantren , yaitu; pondok, masjid, pengajian kitab-kitab klasik, santri dan Kyai. Kelima macam itu adalah pilarpilar dalam suatu pesantren. Pada sistem madrasah tidak mesti ada pondok, masjid dan pengajian kitabkitab klasik. Elemen-elemen yang diutamakan dimadrasah adanya lokal tempat belajar guru, siswadan rencana pelajaran, pimpinan.

Berdasarkan ungkapan diatas dapat dipahami bahwa sistem madrasah mirip dengan sistem sekolah umum di Indonesia. Para siswa tidak mesti tinggal mondok di komplek madrasah, siswa cukup datang kemadrasah pada jam-jam berlangsung pelajaran pada pagi hari atau siang hari. Demikian halnya tidak mesti ada masjid di lingkungan madrasah, kalau siswa bermaksud melaksanakan shalat mereka melaksanakan di mushola. Pengajian kitab-kitab klasik pun tidak

${ }^{1}$ Haidar putra duly, Sejarah Pertumbuhan Dan Pembaruan Pendidikan Islam, (Jakarta: Kencana Media, 2012), h. 93. 
diadakan di madrasah. Pelajaranpelajaran yang akan diajarkan telah tercantum dalam daftar pelajaran yang diuraikan dari kurikulumnya.

Ditinjau dari segi tingkatanya, madrasah dibagi kepada :

a. Tingkat Ibtidaiyah ( Tingkat

b. Tingkat Tsanawiyah(Tingkat Menengah)

c. Tingkat Aliyah ( Tingkat Menengah Atas) ${ }^{2}$.

\section{Perkembangan Madrasah di} Indonesia.

a. Sebelum Kemerdekaan Indonesia

Madrasah yang pertama pertama di Indonesia, adalah madrasah adabiah di padang, yang didirikan oleh Syekh Abdullah Ahmad pada tahun1909. Nama resminya pada masa itu adalah Adabiyah School. Pada masa itu memang pengertian madrasah dan sekolah sama saja, tetapi penggunaan istilah madrasah nampaknya belum dikenal secara umum. Madrasah adabiyah pada mulanya bercorak agama sematamata,tetapi kemudian pada tahun 1915 berubah coraknya menjadi H.I.S (Holand Inland School) Adabiyan. HIS Adabiyah merupakan sekolah pertama yang memasukan pelajaran agama kedalamnya. Kemudian pada tahun 1910 didirikanlah sebuah Madrasah School ( Sekolah Agama) yang dalam perkembanganya berubah menjadi Diniah School( Madrasah Diniah). Dan nama Diniyah School inilah, yang kemudian berkembang dan terkenal. ${ }^{3}$
Madrasah diniyah kemudian berkembang hampir diseluruh Indonesia, baik merupakan bagian dari pesantren atau surau maupun berdiri di luarnya. Pada tahun 1918 di Yogyakarta berdiri madrasah muhamadiyah yang kemudian diubah namanya Madrasah Mualimin Muhamadiyah sebagai realisasi dari cita-cita pembaharuan Pendidikan Islam yang di pelopori oleh K.H. Ahmad Dahlan. Sementara itu pada tahun 1916 dilingkungan podok pesantren Tebuireng, Jombang telah didirikan madrasah shalafiyah, oleh K.H. Hasyim Asy'ari, sebagai persiapan untuk melanjutkan pelajaran kepesantren. Pada tahun 1929 diadakan baharuan dengan memasukan pengetahuan umum.

Dari uraian diatas dapat dikatakan bahwa awal abad ke 20 adalah merupakan masa pertumbuhan dan perkembangan madrasah di seluruh Indonesia dengan nama dan tingkatan yang bervariasi. Namun dapat dikatakan bahwa madrasah-madrasah tersebut pada awal perkembanganya masih bersifat diniyah semata-mata. Baru sekitar pada tahun 1930 terjadi pembaharuan dalam dunia madrasah, yaitu dengan mulai masuknya pengetahuan umum dalam kurikulumnya.

Sebagaimana dengan pesantren, adalah merupakan lembaga mandiri yang sangat tergantung kepada kemampuan pendirinya. Ada sementara madrasah yang hanya mampu menyelenggarakan

${ }^{2}$ Ibid., h. 94

${ }^{3}$ Proyek pembinaan prasarana dan sarana perguruan Pendidikan Islam Di Indonesia, (Jakarta: Kencana tinggi IAIN Jakarta Departemen Agama RI, Sejarah Media, 2012), h. 93. 
pendidikan tingkat awal sampai dengan tingkat tinggi, Disamping itu, terdapat variasi dalam rencana pembelajaranya baik dalam tingkatan maupun materi pelajaranya. Walupun tidak ada pembagian tingkatan seperti Ibtidaiyah (dasar) Tsanawiyah (menengah) dan Aliyah (atas) namun diantara madrasah yang satu dengan lainyabelum terdapat keseragaman isi atau kurikulum serta rencana pelajaran. Pembaharuan sebelum masa kemerdekaan belum mengarah kepada penyeragaman bentuk, sistem dan rencana pelajaran. Usaha kearah penyatuan dan penyeragaman sistem tersebut, baru dirintis setelah Indonesia merdeka, yaitu sekitar tahun 1950.

b. Perkembangan manajemen madrasah awal kemerdekaan sampai orde baru.

Madrasah sebagai lembaga penyelenggara pendidikan diakui oleh Negara secara formal pada tahun 1950. Undang-Undang No. 4 tahun 1950 tentang dasar-dasar pendidikan dan pengajaran di sekolah pada pasal 10 disebutkan" belajar di sekolah agama yang telah mendapat pengakuan Kementrian Agama, madrasah harus memberikan pelajaran agama sebagai mata pelajaran pokok paling sedikit enam jam seminggu secara teratur disamping mata pelajaran umum.

Perubahan yang terjadi pada madrasah dimulai dengan dibukanya Madrasah Wajib Belajar 4 Ramayulis, Sejarah Pendidikan Islam, (Jakarta: (MWB) pada awal tahun 50an oleh Kalam mulia, 2012), h. 350.

Kementrian Agama di bawah
Menteri Agama K.H Wahid Hasyim. Tujuan MWB ini diarahkan kepada pengembangan jiwa bangsa, yaitu pengembangan di bidang ekonomi, industri dan trasnmigrasi dengan kurikulum yang menyelaraskan tiga perkembangan yaitu, perkembangan otak, perkembangan hati, dan perkembangan ketrampilan tangan. ${ }^{4}$

Lama belajar MWB ini 8 tahun dengan pertimbangan, bahwa pada umur 6 tahun anak sudah berhak sekolah, dan pada umur 15 tahun sesuai dengan undang-undang perburuhan, dimana pada umur tersebut anak telah diijinkan untuk mencari nafkah.

Disamping itu adanya MWB ini dimaksudkan sebagai usaha awal untuk memberikan bantuan dan pembinaan madrasah dalam rangka penyeragaman materi kurikulum dan sistem penyelenggaraanya, dalam upaya meningkatkan mutu madrasah Ibtidaiyah

Namun kenyataanya MWB ini tidak berjalan sebagaimana yang diharapkan diantara faktor penyebabnya adalah;

1) Keterbatasan sarana dan prasarana.

2) Ketidakmampuaan pemerintah dalam mempersiapkan guru.

3) Kurang antusiasnya masyarakat dan penyelenggaraan madarsah.

4) Masyarakat menganggap dengan porsi $25 \%$ mata pelajaran Agama, maka MWB kurang 
memenuhi persyaratan sebagai lembaga pendidikan agama.

Tampaknya pengalaman tersebut, telah mendorong pemerintah untuk mendirikan madrasah-madrasah negeri, secara lengkap dan terinci baik dalam penjagaan maupun materi kurikulum serta sistem penyelenggaraanya.

Akhirnya pemerintah mendirikan sistem madrasah yang lebih memenuhi persyaratan dan keinginan masyarakat, madrasah tersebut terdiri dari tiga tingkatan, yaitu:

1) Madrasah Ibtidaiyah lama pendidikan 6 tahun.

2) Madrasah Tsanawiyah pertama lama pendidikan 4 tahun

3) Madrasah Tsanawiyah atas dengan lama pendidikan 4 tahun. Penjejangan ini dibahas oleh Mahmut Yunus sebagai kepala seksi Islam pada kantor agama propinsi, sedangkan kurikulum yang diselenggrakan terdiri atas sepertiga pelajaran agama dan sisanya pelajaran umum. Rumusan kurikulum seperti itu bertujuan, untuk merespon pendapat umum yang menyatakan bahwa madrasah tidak cukup mengajarkan agama saja, dan untuk menjawab kesan tidak baik yang melekat pada madrasah, yaitu pelajaran umum madrasah tidak akan mencapai tingkat yang sama bila dibandingkan dengan sekolah negeri/umum.

Perkembangan madrasah yang cukup penting pada masa orde lama adalah berdirinya Pendidikan Guru Agama (PGA) dan Pendidikan Hakim Islam Negeri (PHIN).
Tujuan mendirikan lembaga ini adalah untuk mencetak tenagatenaga professional yang siap mengembangkan madrasah sekaligus ahli dalam bidang keagamaan. Pendidikan guru agama sebenarnya sudah ada sebelum kemerdekaan di wilayah minangkabau, yang pada masa itu dinamakan Normal School, yang didirikan oleh Mahmut Yunus, dan dari normal school inilah Kementrian Agama mendirikan PGA.

Sejarah perkembangan PGAN dan PHIN bermula dari program Departemen Agama yang ditangani oleh Abdullah Sigit sebagai penanggung jawabbagian pendidikan di Departemen Agama. Pada tahun1950, bagian itu membawa 2 lembaga pendidikan dan madrasah profesional keguruan, yaitu (1) Sekolah Guru Agama Islam (SGAI) dan Sekolah Guru Hakim Agama Islam (SGHIN). SGAI terdiri dari 2 jenjang (a) jenjang jangka panjang yang di tempuh lima tahun dan peruntukan bagi siswa tamatan SR/MI, dan (b) jenjang jangka pendek yang ditempuh selama 2 tahun diperuntukan bagi siswa bagi lulusan SMP/ Madrasah Tsanawiyah. Sedangkan SGHI ditempuh selama 4 tahun diperuntukan bagi lulusan SMP/ Madrasah Tsanawiyah. SGHAI memiliki 4 bagian;

a) Bagian A, untuk mencetak Guru Kesusteraan.

b) Bagian B, untuk mencetak Guru Ilmu Alam.

c) Bagian C, untuk mencetak Guru Agama. 
d) Bagian D, untuk mencetak Guru Pendidian Agama 5

Pada tahun 1951 sesuai dengan Ketetapan Menteri Agama pada 15 Februari 1951, kedua madrasah keguruan tersebut diatas diubah namanya. SGAI menjadi PGA(Pendidikan Guru Agama) dan SGHAI menjadi SGHA (Sekolah Guru Hakim Agama). Pada tahun ini, PGA Negeri didirikan di Tanjung Pinang, Padang, Banjarmasin, Jakarta Tanjung Karang, Bandung dan Pamekasan sedangkan SGHA pada tahun 1951 didirikan di Aceh, Bukit Tinggi dan Bandung.

Pada masa H.M Arifin yang menjadi Kepala Jawatan Pendidikan Agama Departemen Agama, didirikan suatu badan untuk mengembangkan pendidikan di Departemen Agama. Ketentuanketentuan tentang PGA dan SGHA disempurnakan Oleh Badan Pengembangan Pendidikan tersebut. PGA yang lima tahun di ubah menjadi 6 tahun, terdiri atas PGA pertama,(4 tahun) dan PGA atas (2 tahun). PGA jangka pendek dan SGHA dihapuskan. Sebagai pengganti SGHA bagian D, didirikan Pendidikan Hakim Islam Negeri (PHIN) dengan waktu belajar 3 tahun.

\section{Tabel :1}

Data jumlah madrasah dan jumlah murid madrasah

Tahun 1955

\begin{tabular}{l|l|l|} 
Tingkat & Jumlah & Jumlah \\
\hline
\end{tabular}

5 Ramayulis, Sejarah Pendidikan Islam, (Jakarta: Kalam mulia, 2012), h. 352

\begin{tabular}{|c|c|c|}
\hline Madrasah & Madrasah & Murid \\
\hline Madrasah & 13.057 & 1.927 .777 \\
\hline Ibtidaiyah & buah & murid \\
\hline $\begin{array}{l}\text { Madrasah } \\
\text { Tsanawiyah }\end{array}$ & 776 buah & $\begin{array}{c}87.932 \\
\text { murid }\end{array}$ \\
\hline $\begin{array}{c}\text { Madrasah } \\
\text { Aliyah }\end{array}$ & 16 buah & $\begin{array}{l}1.881 \\
\text { murid }\end{array}$ \\
\hline Jumlah & 13.849 & $\begin{array}{c}2.017 .590 \\
\text { murid }\end{array}$ \\
\hline
\end{tabular}

Sumber. Mahmud yunus, Sejarah Pendidikan Islam di indonsia, 1985, hlm 394

1) Perkembanganmanajemen madrasah pada masa orde baru (1965-1997).

a) Perkembangan madrasah sebelum undang-undang nomor 2 tahun 1989 tentang sistem Pendidikan Nasional.

Perubahan pada madrasah dilanjutkan pada masa orde baru. Sewaktu Departemen Agama dipimpin oleh DR. Mukti Ali, MA, beliau mengeluarkan Surat Keputusan bersama Menteri Agama, Menteri Pendidikan dan Kebudayaan dan Menteri Dalam Negeri NO.6 tahun1975, NO 037/U/1975dan NO 36tahun 1975 tanggal 24 Maret 1975 tentang peningkatan mutu pendidikan madrasah. Keputusan bersama tersebut merupakan pelaksanaan dari keputusan Presiden NO 5 tahun 1972 dan instruksi Presiden NO. 15 tahun 1974, sesuai dengan petunjuk Presiden pada sidang kabinet terbatas pada tanggal 26 November 1974.

Menurut SKB 3 Menteri tersebut yang dimaksud dengan madrasah adalah lembaga pendidikan yang menjadikan 
mata pelajaran Agama Islam sebagai mata pelajaran dasar, yang diberikan sekurangkurangnya $30 \%$ disamping mata pelajaran umum. Sementara itu madrasah mencangkup tiga tingkatan, yaitu;

1. Madrasah Ibtidaiyah, setingkat SD.

2. Madrasah Tsanawiyah setingkat SMP.

3. Madrasah Aliyah setingkat SMA.

Dalam rangka merealisasikan SKB 3 Menteri tersebut, maka pada tahun 1976 Departemen Agama menetapkan kurikulum setandar untuk dijadikanacuan oleh madrasah,baik untuk MI, MTs maupun MA.

Kurikulum yang dikeluarkan tersebut juga dilengkapi dengan:

1. Pedoman dan aturan penyelenggaraan pendidikan dan pengajaran pada madrasah, sesuai dengan aturan yang berlaku pada sekolah-sekolah umum.

2. Deskripsi berbagai kegiatan danmetode penyampaian program untuk setiap bidang studi, baik untuk bidang studi agama maupun bidang studi pengetahuan umum.

Dengan diberlakukanya kurikulum standar yang menjadi acuan, maka telah terjadi keseragaman madrasah dalam bidang studiagama, baik kualitas maupun kuantitasnya.Kemudian adanya pengakuan persamaan yang sepenuhnya antara madrasah-madrasah dengan sekolah-sekolahumum yang setaraf, serta madrasah akan mampu berperan sebagai lembaga pendidikan yang memenuhi dan sesuai dengan kebutuhan masyarakat dan mampu berpacu dengan sekolahsekolah umum dalam rangka mencapai Tujuan Pendidikan Nasional.

Adapun SKB 3 menteri tersebut menetapkan;

1) Ijasah madrasah dapat mempunyai nilai yang sama dengan nilai ijasah sekolah umum yang setingkat.

2) Lulusan madrasah dapat melanjutkan kesekolah umum setingkat lebih atas.

3) Siswa madrasah dapat berpindah kesekolah umum yang setingkat. ${ }^{6}$

Untuk pengelolaan madrasah dan pembinaan pendidikan agama menurut SKB 3 Menteri ini, dilakukan oleh Menteri Agama, sedangkan pembinan dan pengawasan mata pelajaran umum pada madrasah dilakukan oleh Menteri Pendidikan dan Kebudayaan bersama-sama Menteri Agama dan Menteri Dalam Negeri.

Kebijaksanaan

peningkatan mutu pendidikan pada madrasah agar sama tingkat/sederajat dengan sekolah umum, diikuti dengan ditertibkan keputusan Menteri Agama RI NO 70 tahun 1976 tentang

6 Azyumrdi azra,Pendidikan Islam: Tradisi dan Modernisasi Menuju Milenium Baru, (Jakarta: Logos, 2012), h. 35 
persamaan tingkat/ derajat madrasah dengan sekolah umum. Keberadaan SKB 3 Menteri ini menyebabkan terjadinya perubahan kurikulum madrasah. Kurikulum Madrasah $60 \%$ Agama dan 40\% Umum berubah menjadi 30\% Agama dan $70 \%$ umum.

SKB 3 Menteri betul memberikan dampak positif bagi madrasah, seperti lulusan Madrasah Ibtidaiyah dapat diterima di SMP Negeri. Siswa lulusan Madrasah Tsanawiyah dapat diterima diSMA Negeri dan lulusan Madrasah Aliah dapat diterima diberbagai Fakultas seperti Fakultas Hukum, Sosial, Ekonomi, Sastra, dan sebagainya, kecuali Fakultas Eksakta. Akan tetapi dalam prakteknya masih ada hambatan dan kelemahan yang perlu diatasi.

1) Perbandingan pelajaran umum dan agama dengan prosentase 70:30 masih menimbulkan reaksi masyarakat sebagai usaha pendangkalan Agama pada Madrasah.

2) Tamatan madrasah serba tanggung pengetahuan agama dan bahasa Arabnya kurang mendalam di anggap sebagai input kurang baik bagi perguruan tinggi Islam, begitu pula pengetahuan umum tamatan madrasah rendah menyebabkan tamatan madrasah kalah bersaing dalam memasuki perguruan tinggi umum dengan siswa SLTA umum.

3) Timbulnya keraguan masyarakat apakah kualitas madrasah dapat menyamai kualitas madrasah sebelum SKB 3 Menteri dan kualitas sekolah umum.

4) Sambutan positif SKB 3 Menteri bagi madrasah belum bisa diimbangi dengan penyedian bantuan tenaga Guru, buku-buku, alat-alat, dan prasarana lainya oleh ketiga Menteri yang terkait dalam SKB 3 Menteri.

SKB 3 Menteri ini diperkuat lagidengan dikeluarkan pula SKB 2 Menteri, antara Menteri Pendidikan dan Menteri Agama NO.0299/U/ 1984 (DIKBUD); NO.045 tahun 1984 (Agama )tentang peraturan pembakuan kurikulum sekolah umum dan sekolah madrasah yang isinya antara lain penyamaan mutu lulusan madrasah dan dapat melanjutkan pendidikan kesekolah-sekolah umum yang lebih tinggi. ${ }^{7}$

SKB 2 Menteri ini dalam rangka penyesuaian sistem pendidikan sejalan dengan adanya kebutuhan pembangunan di segala bidang, antara lain dilakukan melalui perbaikan kurikulum sebagai salah satu upaya perbaikan penyelenggara

\footnotetext{
7 Ramayulis, Sejarah Pendidikan Islam, (Jakarta:
} Kalam mulia, 2012), h. 357 
pendidikan, baik dimadrasah maupun sekolah umum.

Substansi dari pembakuan kurikulum sekolah umum dan madrasah ini antara lain:

1) Kurikulum sekolah umum dan madrasah terdiri dari program inti dan program khusus.

2) Program inti untuk memenuhi tujuan pendidikan pada sekolah umum dan madrasah secara kualitatif.

3) Program khusus (pilihan) diadakan untuk memberikan bekal kemampuan siswa yang akan melanjutkan keperguruan tinggi bagi sekolah dan madrasah tingkat menengah atas.

4) Pengaturan pelaksanaan kurikulum sekolah dan madrasah mengenai sistem kredit, bimbingan karier, ketuntasan belajar dan sistem penilaian adalah sama.

5) Hal-hal yang berhubungan dengan tenaga guru dan sarana pendidikan dalam rangka keberhasilan pelaksanaan kurikulum akan diatur bersama oleh kedua departemen tersebut.

Menindaklanjuti SKB 2 Menteri tersebut lahirlah kurikulum 1984 untuk madrasah, yang tertuang dalam keputusan Menteri Agama nomor 99 tahun 1894 untuk Madrasah Ibtidaiyah, nomor 100 tahun 1984 Madrasah Tsanawiyah dan nomor 101 tahun 1984 untuk Madrasah Aliah. Dengan demikian kurikulum 1984 tersebut pada hakikatnya mengacu pada SKB 3 Menteri dan SKB 2 Menteri baik dalam susunan program, tujuan maupun bahan kajian dan pelajaranya.

2) Perkembangan manajemen madrasah dalam pelaksanaan $U U$ RI No 2 tahun 1989 tentang SISPENAS.

Langkah-langkah strategis lainya dalam rangka pengembangan madrasah menjadi sekolah umum dapat diwujudkan setelah diberlakukanya undang-undang No.2 tahun 1989 tentang Sistem Pendidikan Nasional (SISPENAS)

Sebagai pelaksanaan undangundang tersebut didalamperaturan Pemerintah No.28.tahun 1990 tentang Pendidikan Dasar dalam Bab III pasal 4 ayat (3) disebutkan bahwa :" Sekolah Dasar dan Sekolah Lanjutan Pertama yang bercirikhas Agama Islam yang diselenggarakan oleh Departemen Agama masing-masing disebut Madrasah Ibtidaiyah dan Madrasah Tsanawiyah" Dipihak lain dalam keputusan Menteri Pendidikan dan Kebudayaan tentang Sekolah Menengah Umum dalam pasal 1 ayat (6) disebutkan bahwa ;" Madrasah Aliyah adalah SMU yang bercirikhas Agama Islam yang diselenggarakan oleh Deparemen Agama.

Sehubungan dengan itu Madrasah Ibtidaiyah, Tsanawiyah, dan Aliyah wajib memberikan bahan kajian minimal sama dengan SD, SLTP dan SMU, disamping bahan kajian lain yang diberikan kepada madrasah tersebut. Madrasah (Ibtidaiyah, Tsanawiyh, Aliyah) mempunyai tugas yang sama dengan sekolah umum (SD,SMP dan SMU), yaitu memberikan kemampuan kepada 
peserta didik untuk mengembangkan kehidupan sebagai pribadi, anggota masyarakat, warga negara dan anggota umat manusia serta mempersiapakanya untuk mengikuti pendidikan yang lebih tinggi. Namun dalam aspek lain madrasah tetap mempunyai ciri khas tersendiri.

Sehubungan dengan hal ini di atas dikeluarkanlah Surat Keputusan Menteri Agama Nomor 372 tahun 1993 tentang kurikulum Pendidikan Dasar berciri khas Agama Islam ( terdiri MI dan MTS) dan nomor 373 tahun 1993 tentang kurikulum madrasah Aliah. ${ }^{8}$

Sewaktu Departemen Agama dipimpin oleh Menteri Agama Prof Munawir Sadjali, MA, terjadi pula pengembangan pada Madrasah Aliayah, yaitu dibukanya Madrasah AliyahProgram Khusus (PAPK). Pembukaan lembaga ini dalam rangka mengatasi kelangkaan ulama. Pembukaan MAPK ini tertuang dalam surat Menteri Agama No.371 tahun 1993 tentang Madrasah Aliah keagamaan yang kurikulumnya dituangkan dalam keputusan Menteri Agama No 374 Tahun 1993.

Dalam MAPK ini terlihat Pendidikan Agama memperoleh porsi porsentase yang lebih tinggi seperti tertuang dalam kurikulum MAPK tahun 1993 (70\% Agama$30 \%$ Umum). Perbandingan kurikulum MAPK (70\% Agama 30\%Umum) secara kurikulum pada hakekatnya dimaksudkan untuk mengembangkan program

${ }^{8}$ Ibid., h. 359

pembibitan calon-calon ulama sehingga pembukaan MAPK pada dasarnya adalah program intensifikasi pendidikan melalui sistem asrama (program tutorial) dan mengembangkan kemahiran berbahasa Arab dan Inggris.

Salah satu yang menonjol dalam penyelenggaraan MAPK ini adalah keterlibatan instansi Pusat dan Daerah secara terpadu dalam suatu tim tersendiri. Ketentuan ini juga tampaknya menunjukan betapa seriusnya program ini dengan adanaya tim khusus. Sementara itu calon-calon siswapun diseleksi secara ketat dan harus memenuhi beberapa persyaratan yaitu:

1) Memiliki ijasah STTB/MTsN

2) Menduduki peringkat/rangking 1-10 serta NEM MTsN pada tingkat penitia penyelenggara EBTAN dengan nilai bahasa arab sekurang-kurangnya 7

3) Berumur maksimal 8 tahun

4) Bersedia tinggal di asrama.

5) Berbadan sehat.

6) Mendapat persetujuan orang tua.

7) Berkelakuan baik.

Melihat syarat-syarat yang tertera diatas, jelas bahwa mereka yang akan diterima di MAPK merupakan siswa Madrasah Tsanawiyah Negeri terbaik minimal dia harus masuk 10 (sepuluh) besar serta nilai bahasa Arab paling rendah 7 (tujuh).

Tentang kurikulum MAPK pada dasarnya merupakan peningkatan kualitas pilihan ilmuilmu Agama yang sudah ada. Pada perkembanganya selanjutnya, tampaknya MAPK yang sudah berjalan, tetap semakin ditingkatkan 
dan dikembangkan, baik secara kuantitas maupun kualitasnya. Dan menurut kurikulum 1994 yang merupakan realisasi UUD Nomor 2 tahun 1989 tentang Sistem Pendidikan Nasional, MAPK diganti namanya menjadi Madrasah Aliyah Keagamaan (MAK).

Usaha peningkatan mutu madrasah terus ditingkatkan oleh pemerintah. Dengan lahirnya UUD Nomor 2 tahun 1989 tentang Sistem Pendidikan Nasional (SISPENAS) dengan segala peraturan pemerintah sebagai pedoman pelaksanaanya, maka kurikulum berbagai jenjang dan jenis pendidikan di madrasah yang sekarang sedang berlaku perlu disesuaikan dengan peraturan perundang-undangan tersebut, seperti yang tercantum dalam pasal 37 UU SISPENAS.

Kurikulum disusun untuk mewujudkan tujuan Pendidikan Nasional dengan memperhatikan tahap perkembangan siswa dan kesesuaian dengan lingkungan, kebutuhan pembangunan nasional, perkembangan ilmu pengetahuan dan teknologi serta kesenian, sesuai dengan sains dan jenjang masingmasing satuan pendidikan.

Dalam memenuhi ketentuan UU tentang SISPENAS, Keputusan Mendikbud dan Keputusan Menteri Agama seperti disebutkan sebelumnya maka madrasah disatu pihak bertanggung jawab sebagai lembaga pendidikan umum yang sama dengan sekolah-sekolah umum, sedangkan pada sisi lain, madrasah memiliki tanggung jawab sebagai lembaga pendidikan Islam.

Dalam rangka memenuhi kebutuhan tersebut Menteri Agama mengeluarkan ketentuan-ketentuan mengenai kurikulum madrasah, salah satu dari ketentuan itu, Menteri Agama mengeluarkan kurikulum madrasah yang baru yang berlaku secara nasional, yang berdasarkan surat keputusan nomor 371 tahun 1993 tentang kurikulum Madrasah Tsanawiyah dan nomor 371 tahun 1993 tentang kurikulum Madrasah Aliyah. Kurikulum mulai diberlakukan pada tahun1994.

Diantara bagian isi pokok ketentuan-ketentuan tersebut ialah mengenai program pengajaran, dimana ditentukan bahwa setiap madrasah pada tingkat masing-masing wajib melaksanakan kurikulum mata pelajaran yang disusun secara nasional.

3) Perkembangan manajemen madrasah masa reformasi (1997sekarang).

a) Perkembangan madrasah pada masa reformasi ini dapat pula di bagi kepada dua periode yaitu:

1) Perkembangan madrasah sebelum pelaksanaan Undang-Undang Nomor 20 tahun 2003 tentang SISDIKNAS.

Dengan adanya disentalisasi pendidikan pada masa reformasi, terjadi berbagai perubahanpada madrasah yaitu; (1) perubahan dalam pengolahan, (2) perubahan dalam pemberdayaan alam (3) perubahan partisipasi masyarakat.

1. Perubahan dalam aspek pengelolahan madrasah. 
Perubahan dalam aspek pengelolan madrasah ada dua bentuk $^{9}$

a. Pengelolaan Daerah

Kabupaten Kota.

Dengan adanya desentralisasi dan otonomi dalam bidang pendidikan terjadi perubahan kewenangan dalam penyelenggaraan pendidikan agama pada sekolah umum dan penyelenggaraan

MI/MTs/MA

diserahkan kepada kabupaten sesuai azas desentralisasi

pemerintah yang meliputi : operasional penyelenggaraan, penjabaran kurikulum, penyediaan tenaga pendidikan, penyediaan sarana dan prasarana, dan penyediaan anggaran.

b. Pengelolaan pemerintah pusat.

Sesuai dengan pembagian kewenangan dalam Undang-Undang No 22 tahun 1999 tentang Otonomi Daerah dan Peraturan Pemerintah No 25 tahun 2000 tentang kewenangan pemerintah dan kewenangan propinsi sebagai daerah otonom mengatur

zuhairini, sejarah pendidikan Islam, (Jakarta: Bumi Ahsana, 2004), hlm. 49 desentralisasi

pendidikan, dimana pengaturan mengenai pendidikan oleh pemerintah pusat hanya terfokus diantara pada:

a. Penetapan standar kompetensi siswa dan warga belajar serta mengatur kurikulum nasional dan penilaian hasilbelajar secara nasional serta pedoman pelaksanaanya.

b. Penetapan materi standar pelajaran pokok.

c. Penetapan persyaratan perolehan dan penggunaan gelar akademik

d. Penetapan pedoman pembiayaan penyelenggaraan pendidikan.

e. Penetapan persyaratan penerimaaan perpindahan, sertifikasi siswa, warga belajar dan mahasiswa.

f. Perubahan dalam aspek pemberdayan madrasah, perubahan akan terlihat dalam pemberdayaan madrasah berupa :(1) pemberdayaan manajemen, meliputi pemberdayaan SDM, 
pengelola

pendidikan, kepala

sekolah, guru,tenaga

administrasi,

pengawas, dan lain sebagainya dan (2) siap memasuki era Manajemen Berbasis Sekolah.

2. Perubahan dalam aspek pemberdayaan madrasah.

Perubahan akan terlihat dalam pemberdayan Madrasah berupa:

a. Pemberdayaan

manajemen, meliputi pemberdayaaan SDM, manusia pengelola pendidikan, kepala sekolah, guru, tenaga administrasi, pengawas dan sebagainyadan siap memasuki era manajemenberbasis sekolah.

b. Pemberdayan sistemya, dari system top down ke bottom upsentralisasi ke desentralisasi.

c. Pemberdayaan

kebijakan yaitu dari kebijakan yang memarjinalkan

madrasah kepada kebijakan yang membawa madrasah ke Center Of Excelent.

d. Pemberdayaan masyarakat dengan melibatkan unsur-unsur masyarakat untuk ikut serta dalam pemberdayaan

Madrasah, dengan cara meningkatkan peran serta stake holderdan akuntabilitas.

3. Perubahan partisipasi masyarakat.

Perubahan partisipasi masyarakat dilihat dari aspek:

- Penampungan aspirasi masyarakat dan memberdayakan masyarakat daerah pada madrasah.

e. Adanya partisipasi masyarakat dalam memilih dan menetapkan visi,misi dan skala prioritas dalam rangkapelaksanaan madrasah.

a. Adanya peluang untuk masuk nilainilai adat dan budaya lokal kedalam kurikulum madrasah.

2) Perkembangan Madrasah dalam pelaksanaan Undangundang nomor 20 tahun 2003 tentang SISDIKNAS.

Fungsi, peranan dan status madrasah secara subtansial pada undangundang NO.20 tahun 2003 ini tidak berbeda dengan madrasah pada undangundangNO.2 tahun 1989. Hanya saja jika dilihat dari yuridisnya, madrsasah pada undang-undang NO.20 tahun 2003 lebih kuat dan kokoh karena penyebutan nomenklatur madrasah masuk dalam batang tubuh undangundang NO.2 tahun 1989, peristilahan madrasah hanya 
datur pada peraturan
pemerintah dan keputusan menteri. Madrasah Tsanawiyah dan Madrasah Ibtidaiyah di jelaskan padaperaturan pemerintah NO.28 tahun 1990. Sedangkan perkataan Madrasah Aliyah disebutkan pada keputusan Menteri Pendidikan dan Kebudayaan NO.489/U/1992. Perkataan madrasah pada undangundang N0 20 taun 2003 dapat ditemukan pada pasal 17 dan 18.

$$
\text { Pada pasal 17: }
$$

Pendidikan dasar berbentuk

Sekolah Dasar (SD)dan

Madrasah Ibtidadiyah (MI) atau bentuk lain yang sederajat serta Sekolah Menegah Pertama (SMP) dan Madrasah Tsanawiyah atau bentuk lain yang sederjat.

Pasal 18: Pendidikan menengah berbentuk Sekolah Menengah Atas (SMA), Madrasah Aliyah (MA) dan Madrasah Aliyah Kejuruan (MAK) atau bentuk lain yang sederajat. ${ }^{10}$

\section{4) Posisi Integrasi Pendidikan Islami dalam SISDIKNAS tercemin dalam aspek.}

Pertama aspek yang paling penting dalam pendidikan nasional adalah menjadikan agama sebagai

${ }^{10}$ Haidar putra duly, Sejarah Pertumbuhan Dan Pembaruan Pendidikan Islam, (Jakarta: Kencana Media, 2012), h. 115. salah satu muatan wajib dalam semua jalur dan jenis pendidikan. Kebijakan ini tentu sangat berarti dalam proses integrasi pendidikan secara nasional, karena telah meyakinkan bahwa SISDIKNAS sebelum ini adalah karena status pendidikan agama yang kurang memuaskan, bahkan pernah diabaikan. Dengan ketentuan yuridis, bahwa pendidikan agama merupakan muatan wajib dari setiap jalur dan jenjang pendidikan, yang membuka wawasan positif dikalangan umat Islam, bahwa antara sekolah dan madrasah tidak memiliki perbedaan yang prinsip.

Kedua, dalam SISDIKNAS, madrasah dengan sendirinya dimasukan kedalam kategori pendidikan jalur sekolah. Jika ini terdapat dualisme antar sekolah dan madrasah. Maka dengan kebijakan ini dapat dikatakan bahwa madrasah pada hakikatnya adalah sekolah. Bahwa pengelolaan madrasah tetap di DEPAG, tidak berarti lembaga pendidikan itu mempertahankan eksklusifitasnya, meskipun tetap bisa mempertahankan ciri-ciri keagamanya. Dalam ukuran yang lebih kuat, ketentuan ini semakin mempertegas kedudukan madrasah yang sebelumnya diatur oleh SKB 3 Menteri.

Ketiga, meskipun madrasah diberi status pendidikan jalur sekolah tetapi sesuai dengan jenis keagamaan dalam SISDIKNAS, Madrasah memiliki jurusan khusus ilmu-ilmu syariah. Pada jurusan yang terahir ini bisa dikatakan bahwa sekitar $70 \%$ dari muatan 
kurikulumnya merupakan bidangbidang studi agama.

Kemantapan eksistensi madrasah pada masa orde baruterus berlanjut sampai sekarang. Hal itu terlihat jelas dengan munculnya UU 20 tahun 2003. Kemantapan itu tidak berubah Madrasah tetap merupakan bagian integral dari SISDIKNAS kendati pengelolaanya masih dilakukan oleh DEPAG. Namun disamping itu ada catatan penting yang mesti diperhatikan oleh kalangan-kalangan yang berkepentingan dengan perkembangan lembaga pendididkan Islam ini, sehubungan dengan adanya perubahan pada bagian-bagian tertentu. ${ }^{11}$

\section{PENUTUP}

Madrasah sebagai aset Bangsa dan Negara telah menunjukkan perannya di Negara Indonesia. Di awali dari pesantren-pesantren hingga lahirnya madrasah. Mulai dari tingkat dasar (Ibtidaiyah) sampai tingkat Aliyah (atas). Begitu besar peran lembaga pendidikan Islam memotivasi para pejuang kemerdekaan pada saat itu. Untuk itu, bagaimana pun kondisi madrasah itu harus kita pertahankan serta kita dorong kearah yang lebih baik sehingga madrasah menjadi idola masyarakat dan bisa bersaing dengan pendidikan umum. Sehingga harapan nilai plus madrasah, penguasaan pendidikan Islam dan bahasa Arab.

${ }^{11}$ Siti zubaidah, Sejarah Pendidikan Islam, (Bandung:Rosdakaraya, 2014) hlm135.
Dalam sistem pendidikan nasional, madrasah dengan sendirinya dimasukkan

kedalam katagori jalur sekolah. Jika sebelumnya terdapat dualisme antara sekolah dan madrasah, maka dengan kebijakan ini dapat dikatakan bahwa madrasah pada hakekatnya adalah sekolah. Mekipun madrasah diberi status pendidikan jalur sekolah, tetapi sesuai dengan jenis keagamaan dalam sistem pendidikan nasional.

Integrasi madrasah ke dalam Sistem Pendidikan Nasional dengan demikian bukan merupakan integrasi dalam arti penyelenggaraan dan pengelolaan pendidikan, termasuk madrasah oleh Departemen Pendidikan Nasional, tetapi lebih kepada pengakuan yang lebih mantab bahwa madrasah adalah bagian dari Sistem Pendidikan Nasional walupun pengelolaanya dilimpahkan kepada Departemen Agama (UU SISDIKNAS, pasal 50).

\section{DAFTAR PUSTAKA}

Azra,Azzumardi. Pendidikan Islam: Tradisi dan Modernisasi Menuju Milenium BaruJakarta: Logos, 2012

Duly,Haidar. Sejarah Pertumbuhan Dan Pembaruan Pendidikan Islam. Jakarta: Kencana Media, 2012.

Hambal, muhamad. Sejarah Pendidikan Islam. Surakarta: Arafah, 2014

Proyek pembinaan prasarana dan sarana perguruan tinggi IAIN Jakarta Departemen Agama RI, Sejarah Pendidikan Islam Di 
Rini Setyaningsih: Manajemen Madrasah dalam Perspektif ...

Indonesia. Jakarta: Kencana

Media, 2012

Ramayulis.Sejarah Pendidikan

Islam.Jakarta: Kalam mulia, 2012

Zubaidah, siti. Sejarah Pendidikan

Islam. Bandung: Rosdakarya, 2014

Zuhairini.Sejarah Pendidikan

Islam. Jakarta: Bumi Aksara, 2004 